\title{
Faktor perilaku meningkatkan resiko keputihan
}

\author{
Umi Salamah, ${ }^{*}$ Djati Wulan Kusumo, ${ }^{2}$ Desi Nurlaela Mulyana ${ }^{3}$ \\ ${ }^{1,3}$ Program Studi Kebidanan, Stikes Prima Indonesia, Bekasi; ${ }^{2}$ Program Studi S1 Farmasi, \\ Stikes Prima Indonesia, Bekasi - Indonesia
}

\begin{abstract}
Reproductive health is a complete state of physical, mental and social well-being. Cleanliness of the female area for women is very important because it can make women feel comfortable and can prevent infectious diseases and infections. This research to determine the relationship of behavioral factors (urinary habits, use of irritants, habits during menstruation, use of underwear), and environmental factors (toilet hygiene) with the occurrence of vaginal discharge in students of the Great Achievement Midwifery Academy. This research uses analytic type with cross sectional approach. The sample of this research is 190 students of the Great Achievement Midwifery Academy, bivariate analysis using chi square. It was found that 134 (70.5\%) respondents experienced vaginal discharge, there was a significant relationship between the use of irritants and vaginal discharge ( $p$ value $=0,000$ and OR $=$ 27.7), there was a significant relationship between the habit of urination and vaginal discharge ( $p$ value $=0,000$ and $\mathrm{OR}=34$ ), there is a significant correlation between the use of underwear with vaginal discharge ( $p$ value $=0.002$ and $O R=36$ ), there is a significant relationship between menstrual habits and vaginal discharge ( $p$ value $=0.006$ and $O R=2.9$ ). The use of irritants, urinary habits, underwear and voiding habits are risk factors for vaginal discharge.
\end{abstract}

Keywords: leucorrhoea; adolescent girls; urinary habits; use of irritants

Kesehatan reproduksi adalah keadaan sejahtera fisik, mental dan sosial secara utuh. Kebersihan daerah kewanitaan bagi perempuan sangat penting karena dapat membuat wanita merasa nyaman dan dapat mencegah dari penyakit serta infeksi menular. Penelitian ini bertujuan untuk mengetahui hubungan faktor perilaku (kebiasaan berkemih, penggunaan iritan, kebiasaan pada saat menstruasi, penggunaan pakaian dalam), dan faktor lingkungan (kebersihan toilet) dengan kejadian keputihan pada mahasiswa Akademi Kebidanan Prestasi Agung. Penelitian ini menggunakan jenis analitik dengan pendekatan cross sectional, Sampel penelitian ini adalah mahasiswa Akademi Kebidanan Prestasi Agung sebanyak 190 mahasiswa, analisis bivariat menggunakan chi square. Penelitian ini menjukkan bahwa 134(70.5\%) responden mengalami keputihan, ada hubungan yang bermakna antara penggunaan iritan dengan keputihan ( $p$ value $=0.000$ dan $\mathrm{OR}=27.7$ ), ada hubungan yang bermakna antara kebiasaan berkemih dengan keputihan ( $p$ value $=0.000$ dan $O R=34$ ), ada hubungan yang bermakna antara penggunaan pakaian dalam dengan keputihan ( $p$ value $=0.002$ dan $O R=36$ ), ada hubungan yang bermakna antara kebiasaan menstuasi dengan keputihan ( $p$ value $=0.006$ dan $\mathrm{OR}=2.9$ ). Penggunaan iritan, kebiasaan berkemih, pakaian dalam dan kebiasaan berkemih merupakan faktor risiko dari keputihan.

Kata Kunci: keputihan; remaja perempuan; kebiasaan berkemih; penggunaan iritan 


\section{Pendahuluan}

Organ reproduksi merupakan salah satu organ tubuh yang sensitif dan memerlukan perawatan khusus. Pengetahuan dan perawatan yang baik merupakan faktor penentu dalam memelihara kesehatan reproduksi (Puspitaningrum, 2012). Salah satu gejala terjadinya kelainan pada organ reproduksi adalah keputihan. Keputihan merupakan gejala yang sering dialami oleh sebagian besar wanita (IImiawati \& Kuntoro, 2016).

Keputihan merupakan kondisi yang sering dialami oleh wanita sepanjang siklus kehidupannya mulai dari masa remaja, masa reproduksi maupun masa menopause (Maryanti \& Wuryani, 2019). Keputihan dibedakan menjadi 2 jenis yaitu keputihan normal atau fisiologis dan abnormal atau patologis (Bagus \& Aryana, 2019). Keputihan normal atau fisiologis terjadi sesuai dengan siklus reproduksi wanita atau sesuai dengan siklus tubuh wanita dengan jenis pengeluaran berwarna bening, tidak berlebihan tidak berbau dan tidak menimbulkan rasa gatal atau perih. Sedangkan keputihan yang patologis atau abnormal ditandai dengan jumlah pengeluaran yang banyak, berwarna putih seperti susu basi, kuning atau kehijauan, gatal, perih, dan disertai bau amis atau busuk. Warna pengeluaran dari vagina akan berbeda sesuai dengan penyebab dari keputihan. Penyebab keputihan abnormal yang tersering adalah bakteri, jamur dan parasit (Marhaeni, 2016).

Keputihan adalah kondisi vagina saat mengeluarkan lendir atau cairan menyerupai nanah yang disebabkan kuman. Terkadang keputihan dapat menimbulkan rasa gatal, bau tidak enak dan berwarna (Bahari, 2012). Kebersihan genitalia yang kurang baik merupakan faktor risiko yang dapat menyebabkan infeksi pada genitalia. Kejadian keputihan sebagai salah satu gangguan kesehatan masih cukup tinggi berhubungan dengan kurangnya pengetahuan remaja tentang vulva hygiene (Mareta, Budi, \& Istiana, 2013).

Menurut Abrori, Hernawan, dan Ermulyadi (2017) faktor penyebab keputihan antara lain tidak mengeringkan genital setelah buang air kecil (BAK), menggunakan pakaian yang ketat, tidak menggunakan pakaian dalam yang berbahan katun, membasuh organ kewanitaan kearah yang salah, tidak segera mengganti pembalut ketika menstruasi, menggunakan sabun pembersih vagina, penggunaan antibiotic dan kondisi stres. Faktor-faktor yang dapat mempengaruhi terjadinya keputihan, tentunya dapat mempengaruhi derajat kesehatan dan kesejahteraan perempuan. Oleh karena itu menjaga kebersihan diri merupakan hal yang sangat penting untuk diperhatikan. Kemampuan seseorang dalam meningkatkan kebersihan genitalia merupakan perilaku yang harus dimiliki untuk mencegah terjadinya infeksi pada genitalia (Omidvar \& Begum, 2011). Perawatan Genitalia eksterna yang tidak baik akan memicu terjadinya keputihan. Faktanya banyak remaja yang tidak mengerti dan peduli bagaimana cara merawat organ reproduksinya (Ayuningtyas \& Suryaatmaja, 2011).

\section{Metode Penelitian}

Penelitian ini menggunakan desain penelitian analitik dengan pendekatan cross sectional. Populasi dalam penelitian ini adalah responden kebidanan dengan jumlah 304 orang, sample yang digunakan berjumlah 190 orang dengan 
menggunakan teknik simple random sampling. Studi pendahuluan yang dilakukan terhadap 20 responden, dimana 60\% (12 responden) mengalami kondisi cairan vagina yang berwarna kuning dan gatal.

\section{Hasil dan Pembahasan}

Tabel 1. tersebut menunjukkan bahwa sebagian besar responden berusia $\geq 19$ tahun sebanyak 176 responden (92,6\%). Sebagian besar responden mempunyai social ekonomi tinggi sebanyak 102 (53,7\%). Sebanyak 114 responden (60\%) menggunakan iritan, sebagian besar responden sudah berkemih dengan baik $(51,6 \%)$, menggunakan pakaian dalam yang baik $(66,3 \%)$, kebiasaan menstuasi sudah baik $(64,7 \%)$, dan kebersihan toilet yang sudah bersih $(63,7 \%)$.

Tabel 2 menunjukkan penggunaan iritan yang mengalami keputihan (93,9\%), sedangkan yang tidak menggunakan iritan dan tidak mengalami keputihan sebanyak $64,5 \%$. dari hasil olah data didapatkan $p$ value $=0,000<0,05$, berarti ada hubungan yang bermakna antara penggunaan iritan dengan keputihan. $O R=27,7$ artinya responden yang menggunakan iritan mempunyai peluang 27,7 kali mengalami keputihan dibandingkan dengan yang tidak menggunakan iritan. Sehingga dapat disimpulkan penggunaan iritan merupakan faktor risiko keputihan.

Tabel 1. Karakteristik Responden

\begin{tabular}{|c|c|c|c|}
\hline No & Variabel & $\mathrm{n}$ & $\%$ \\
\hline \multirow[t]{3}{*}{1} & Usia & & \\
\hline & $<19$ tahun & 14 & 7.4 \\
\hline & $\geq 19$ tahun & 176 & 92,6 \\
\hline \multirow[t]{3}{*}{2} & Sosial Ekonomi & & \\
\hline & Rendah & 88 & 46.3 \\
\hline & Tinggi & 102 & 53,7 \\
\hline \multirow[t]{3}{*}{3} & Penggunaan Iritan & & \\
\hline & Ya & 114 & 60 \\
\hline & Tidak & 76 & 40 \\
\hline \multirow[t]{3}{*}{4} & Kebiasaan Berkemih & & \\
\hline & Kurang Baik & 92 & 48.4 \\
\hline & Baik & 98 & 51,6 \\
\hline \multirow[t]{3}{*}{5} & Penggunaan Pakaian Dalam & & \\
\hline & Kurang Baik & 64 & 33,7 \\
\hline & Baik & 126 & 66,3 \\
\hline \multirow[t]{3}{*}{6} & Kebiasaan Menstruasi & & \\
\hline & Kurang Baik & 67 & 35,3 \\
\hline & Baik & 123 & 64,7 \\
\hline \multirow[t]{3}{*}{7} & Kebersihan Toilet & & \\
\hline & Kurang Bersih & 69 & 36,3 \\
\hline & Bersih & 121 & 63,7 \\
\hline
\end{tabular}


Tabel 2.

Tabel silang hubungan penggunaan iritan dengan keputihan

\begin{tabular}{|c|c|c|c|c|c|c|}
\hline \multirow{3}{*}{$\begin{array}{c}\text { Penggunaan } \\
\text { Iritan }\end{array}$} & \multicolumn{4}{|c|}{ keputihan } & \multicolumn{2}{|c|}{ Total } \\
\hline & \multicolumn{2}{|c|}{$\mathrm{Ya}$} & \multicolumn{2}{|c|}{ Tidak } & \multirow[b]{2}{*}{$f$} & \multirow[b]{2}{*}{$\%$} \\
\hline & $f$ & $\%$ & $f$ & $\%$ & & \\
\hline Ya & 107 & 93,9 & 7 & 61,6 & 114 & 100 \\
\hline Tidak & 27 & 35,5 & 49 & 64,5 & 76 & 100 \\
\hline Jumlah & 134 & 70,5 & 56 & 29,5 & 190 & 100 \\
\hline
\end{tabular}

Sebagian perempuan telah mengenal dan menggunakan sabun sirih yang dijual bebas untuk membersihkan organ reproduksinya, dengan alasan untuk kebersihan. Secara alamiah dalam setiap vagina terdapat bakteri baik (flora normal vagina). Bakteri baik itu berfungsi mengusir kuman yang merugikan. Pemakaian sabun vagina berlebihan justru membunuh bakteri baik yang kemudian mempermudah kuman masuk ke vagina sehingga mengurangi tingkat keasaman vagina, dampaknya kuman dan jamur akan banyak menginfeksi (Utami \& Anggraini, 2018). Dampak lain penggunaan pembersih vagina berlebihan dapat menyebabkan mikroflora normal pada vagina terbunuh dan menimbulkan iritasi pada vagina. Iritasi pada permukaan mukosa vagina menyebabkan mudah terjadi terinfeksi oleh kuman, bakteri, jamur, dan virus penyebab keputihan patologis (Bahari, 2012).

Sebagian perempuan telah mengenal dan menggunakan sabun sirih yang dijual bebas untuk membersihkan organ reproduksinya, dengan alasan untuk kebersihan (Mustika, Astini, \& Yunianti, 2014). Secara alamiah dalamsetiap vagina terdapat bakteri baik (flora normal vagina). Bakteri baik itu berfungsi mengusir kuman yang merugikan. Pemakaian sabun vaginaberlebihan justru membunuh bakteri baik yang kemudian mempermudah kuman masuk ke vagina sehingga mengurangi tingkat keasaman vagina. Dampaknya, kuman jahat hidup subur, jamur salah satunya (Utami \& Anggraini, 2018).

Berdasarkan tabel 3 dapat diketahui bahwa kebiasaan berkemih yang buruk dapat meningkatkan risiko terjadinya keputihan $(96,7 \%)$. Berdasarkan hasil penelitian, kemudian dilakukan analisa data dengan menggunakan perhitungan statistic melalui uji ChiSquare didapatkan $p$ value $=0,000<0,05$, berarti ada hubungan antara kebiasaan berkemih dengan kejadian keputihan. $\mathrm{OR}=34$ artinya responden yang memiliki kebiasaan berkemih buruk memiliki peluang 34 kali mengalami keputihan dibandingkan dengan yang memiliki kebiasaan berkemih yang baik.

Pada penelitian ini kebiasaan berkemih yang kurang baik ditunjukkan dari beberapa kebiasaan seperti tidak menyiapkan tisu atau handuk kering saat ingin buang air kecil (BAK) atau buang air besar (BAB), tidak mengeringkan area genitalia setelah $B A K$ atau $B A B$ dan tidak membersihkan dudukan toilet duduk sebelum digunakan. Pada penelitian ini kebiasaan berkemih yang kurang baik ditunjukkan dari beberapa kebiasaan respon- 
Tabel 3.

Tabel silang hubungan kebiasaan berkemih dengan keputihan

\begin{tabular}{|c|c|c|c|c|c|c|}
\hline \multirow{3}{*}{$\begin{array}{l}\text { Kebiasaan } \\
\text { berkemih }\end{array}$} & \multicolumn{4}{|c|}{ Keputihan } & \multicolumn{2}{|c|}{ Total } \\
\hline & \multicolumn{2}{|c|}{$\mathrm{Ya}$} & \multicolumn{2}{|c|}{ Tidak } & \multirow[b]{2}{*}{$f$} & \multirow[b]{2}{*}{$\%$} \\
\hline & $f$ & $\%$ & $f$ & $\%$ & & \\
\hline Buruk & 89 & 96,7 & 3 & 3,3 & 92 & 100 \\
\hline Baik & 45 & 45,9 & 53 & 54,1 & 98 & 100 \\
\hline Jumlah & 134 & 70,5 & 56 & 29,5 & 190 & 100 \\
\hline
\end{tabular}

Tabel 4.

Tabel silang hubungan penggunaan pakaian dalam dengan keputihan

\begin{tabular}{crrrrrrr}
\hline $\begin{array}{c}\text { Penggunaan } \\
\text { pakaian } \\
\text { dalam }\end{array}$ & \multicolumn{3}{c}{ keputihan } & \multicolumn{2}{c}{ Total } \\
\cline { 1 - 6 } & \multicolumn{2}{c}{ Ya } & \multicolumn{3}{c}{ Tidak } & & \\
\hline Buruk & 55 & 85,9 & 9 & 14,1 & 64 & 100 \\
Baik & 79 & 62,7 & 47 & 37,3 & 126 & 100 \\
\hline Jumlah & 134 & 70,5 & 56 & 29,5 & 190 & 100 \\
\hline
\end{tabular}

den seperti membersihkan area genitalia dengan cara yang benar, yaitu dari arah depan ke belakang, kebiasaan mencuci tangan sebelum dan sesudah BAK atau BAB dan memberishkan area genitalia dengan menggunakan air mengalir.

Ketika berada di toilet umum, sebaiknya jangan menggunakan air di ember atau penampungan untuk membersihkan. Sebaiknya gunakan saja air yang berasal dari keran yang mengalir, hal ini akan lebih aman. Karena menurut penelitian air yang tergenang di toilet umum mengandung $70 \%$ jamur candida albicans penyebab keputihan. Sedangkan air yang mengalir di dalam keran mengandung kurang lebih hanya 10-20\% (Marhaeni, 2016).
Berdasarkan Tabel 4 dapat diketahui bahwa penggunaan pakaian dalam yang kurang baik dapat meningkatkan risiko terjadinya keputihan $(85,9 \%)$. Berdasarkan hasil penelitian, kemudian dilakukan analisa data dengan menggunakan perhitungan statistik melalui uji Chi Square didapatkan $p$ value $=0,002<0,05$, berarti ada hubungan antara penggunaan pakaian dalam dengan kejadian keputihan. $\mathrm{OR}=3,6$ artinya responden yang penggunaan pakaian dalam kurang baik memiliki peluang 3,6 kali mengalami keputihan dibandingkan dengan yang menggunakan pak-aian dalam yang baik. 
Tabel 5.

Tabel silang hubungan kebiasaan menstruasi dengan keputihan

\begin{tabular}{|c|c|c|c|c|c|c|}
\hline \multirow{3}{*}{$\begin{array}{l}\text { Kebiasaan } \\
\text { menstruasi }\end{array}$} & \multicolumn{4}{|c|}{ keputihan } & \multicolumn{2}{|c|}{ Total } \\
\hline & & $a$ & & idak & & \\
\hline & $\mathbf{F}$ & $\%$ & $f$ & $\%$ & $f$ & $\%$ \\
\hline Buruk & 56 & 83,6 & 11 & 16,4 & 67 & 100 \\
\hline Baik & 78 & 63,4 & 45 & 36,6 & 123 & 100 \\
\hline Jumlah & 134 & 70,5 & 56 & 29,5 & 190 & 100 \\
\hline
\end{tabular}

Menurut Janah, Sampurno, dan Wahyuningsih (2013) gunakanlah celana dalam yang bersih dan berbahan katun 100 persen bila ingin menggunakannya dalam waktu yang lama. Celana dalam berbahan nilon dan polyester (karena berbagai pertimbangan estetika dan eksplorasi keseksian lebih banyak digunakan) akan menambah panas dan lembab vagina sehingga bakteri mudah berkembang biak.

Hasil penelitian ini sesuai dengan yang dikemukakan oleh Bahari (2012) penyebab keputihan abnormal dapat disebabkan oleh mengenakan pakaian berbahan sintesis yang ketat sehingga ruang yang ada tidak memadai, sehingga timbul iritasi pada organ kewanitaan.

Responden yang memiliki kebiasaan menstruasi yang kurang baik dan mengalami keputihan sebesar $83,6 \%$ dan responden yang memiliki kebiasaan menstruasi yang baik dan mengalami keputihan sebesar $63,4 \%$ dan $P$ value $(P=0,006<0,05)$, terdapat perbedaan yang signifikan antara responden yang memiliki kebiasaan menstruasi yang baik dan responden yang memiliki kebiasaan menstruasi yang kurang baik dengan kejadian keputihan, artinya ada hubungan antara kebiasaan menstruasi dengan keputihan, dari hasil OR didapat 2,9 artinya yang memiliki kebiasaan menstruasi kurang baik 2,9 kali berisiko mengalami keputihan dibanding dengan yang memiliki kebiasaan menstruasi yang baik.

\section{Kesimpulan}

Secara umum responden yang mengalami keputihan sebesar 134 (70,5\%). Sebagian besar responden yang menggunakan iritan sebanyak 114 (60\%). Sebagian besar responden memiliki kebiasaan berkemih yang kurang baik sebanyak 92 (48,4\%). Ada hubungan bermakna antara penggunaan iritan dengan keputihan ( $\mathrm{p}$ value $=$ $0,000 \mathrm{OR}=27,7)$. Ada hubungan antara kebiasaan berkemih dengan keputihan ( $p$ value $=0,000$ $\mathrm{OR}=34)$. Ada hubungan antara penggunaan pakaian dalam dengan keputihan ( $p$ value $=0,002$ $\mathrm{OR}=3,6)$. Ada hubungan antara kebiasaan berkemih dengan keputihan ( $p$ value $=0,006$ $\mathrm{OR}=2,9$ ).

\section{Daftar Pustaka}

Abrori, A., Hernawan, A. D., \& Ermulyadi, E. (2017). Faktor yang berhubungan dengan kejadian keputihan patologis siswi SMAN 1 Simpang 
Hilir Kabupaten Kayong Utara. Unnes Journal of Public Health, 6(1), 24-34. https://doi.org/10.15294/ujph.v6i1.14107

Ayuningtyas, D. N., \& Suryaatmaja, L. (2011). Hubungan antara pengetahuan dan perilaku menjaga kebersihan genetalia eksterna dengan kejadian keputihan pada siswi SMA Negeri 4 Semarang. Universitas Diponegoro, Semarang. Diambil dari http://eprints.undip.ac.id/32942/

Bagus, M., \& Aryana, D. (2019). Gambaran pengetahuan, sikap, dan perilaku tentang vaginal hygiene terhadap kejadian keputih an patologis pada siswi kelas 1 di SMA Negeri 1 Denpasar periode Juli 2018, 10(1), 88-94. https://doi.org/10.1556/ism.v10i1. 357

Bahari, H. (2012). Cara mudah atasi keputihan. Yogyakarta: Buku Biru.

Ilmiawati, H., \& Kuntoro, K. (2016). Pengetahuan personal hygiene remaja putri pada kasus keputihan. Jurnal Biometrika dan Kependudukan, 5(1), 43-51. https://doi.org/ 10.20473/jbk.v5i1.2016.43-51

Janah, A. F., Sampurno, E., \& Wahyuningsih, W. (2013). Perilaku vulva hygiene berhubungan dengan kejadian keputihan pada remaja putri kelas XII SMA Gama 3 Maret Yogyakarta. Journal Ners and Midwifery Indonesia, 1(2), 66-70. https://doi.org/ 10.21927/jnki.2013.1(2).66-70

Mareta, P. W., Budi, M., \& Istiana, S. (2013). Hubungan pengetahuan remaja putri tentang personal hygiene tindakan pencegahan keputihan di SMA Negri 9
Semarang tahun 2012. Jurnal Kebidanan, 2(1), 72-76. https://doi.org/10.26714/jk.2.1. 2013.72-76

Marhaeni, G. A. (2016). Keputihan pada wanita. Jurnal Skala Husada, 3(1), 30-38.

Maryanti, S., \& Wuryani, M. (2019). Persepsi dan perilaku remaja putri dalam mencegah keputihan di SMK 1 Lambuya Kabupaten Konawe. Jurnal SMART Kebidanan, 6(2), 6569. https://doi.org/10.34310/sjkb.v6i2.267

Mustika, W., Astini, P. S. N., \& Yunianti, N. P. (2014). Penggunaan air rebusan daun sirih terhadap keputihan fisiologis di kalangan remaja putri mahasiswa Poltekes Denpasar. Jurnal Skala Husada, 11(1), 101-106.

Omidvar, S., \& Begum, K. (2011). Menstrual pattern among unmarried women from South India. Journal of Natural Science, Biology and Medicine, 2(2), 174-179. https://doi.org/ $10.4103 / 0976-9668.92329$

Puspitaningrum, D. (2012). Faktor-faktor yang mempengaruhi praktik perawatan organ genitalia eksternal pada anak usia 10-11 tahun yang mengalami menarche dini di sekolah. In Seminar Hasil-Hasil Penelitian 2012 Unimus Semarang.

Utami, U., \& Anggraini, Y. (2018). Perilaku personal hygiene remaja putri pada saat menstruasi di SMP N 1 Masaran. Jurnal Ilmiah Maternal, 2(3). Diambil dari https://ejurnal. stikesmhk.ac.id/index.php/jurnal_ilmiah_m aternal/article/view/640 
This page is intentionally left blank 